\title{
The effects of the process parameters in electrochemical machining on the surface quality
}

\author{
Nguyen Thi Bich Nhung ${ }^{1}$, Dao Thanh Liem ${ }^{2}$, Truong Quoc Thanh ${ }^{2, *}$
}

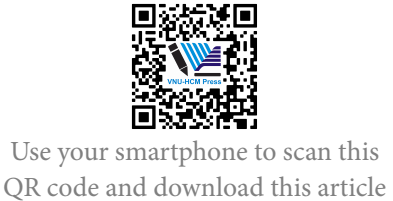

${ }^{1}$ SEAS Project Consultants Co, Ltd; 8/19a Nguyen Thien Thuat Str., Ward 24th, Binh Thanh Dist, Ho Chi Minh City Vietnam

${ }^{2}$ Faculty of Mechanical Engineering, University of Technology, VNU-HCM, 268 Ly Thuong Kiet Str., Ward 14th, 10th Dist, Ho Chi Minh City, Vietnam

\section{Correspondence}

Truong Quoc Thanh, Faculty of Mechanical Engineering, University of Technology, VNU-HCM, 268 Ly Thuong Kiet Str., Ward 14th, 10th Dist, Ho Chi Minh City, Vietnam

Email: tqthanh@hcmut.edu.vn

History

- Received: 10/10/2018

- Accepted: 23-12-2018

- Published: 31-12-2019

DOI : 10.32508/stdjet.v3iSI1.725

\section{Check for updates}

\section{Copyright}

( ) VNU-HCM Press. This is an openaccess article distributed under the terms of the Creative Commons Attribution 4.0 International license.

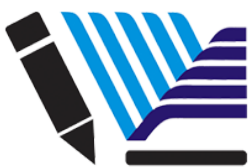

VNU-HCM Press

ABSTRACT

Based on the number of previous studies, this study aims to investigate the effects of process parameters of an Electrochemical Machining process which are electrolyte concentration, voltage applied to the machine, feed rate of the electrode and Inter-Electrode Gap between tool and work - piece. Aluminum samples of $25 \mathrm{~mm}$ diameter $\times 25 \mathrm{~mm}$ height and $30 \mathrm{~mm}$ diameter $\times 25 \mathrm{~mm}$ height of the tool is made up of copper with a circular cross section with $2 \mathrm{~mm}$ internal hole. The design of the system is based on the Taguchi method. Here, the signal-to-noise (S/N) model, the analysis of variance (ANOVA) and regression analyses are applied to determine optimal levels and to investigate the effects of these parameters on surface quality. Finally, the experiments that use the optimal levels of machining parameters are conducted to verify the effects of the process parameters to the surface quality of the products. The results pointed a set of optimal parameters of the ECM process. The Inter-Electrode Gap between tool and work - piece has extremely effected on these Material Removal Rate and surface roughness. The Material Removal Rate increases with diseases in Inter-Electrode Gap, and Ra diseases with diseases in Inter-Electrode Gap. The experimental results show that maximum Material Removal Rate have obtained with electrolyte concentration at $100 \mathrm{~g} / \mathrm{l}$, feed rate at $0.0375 \mathrm{~mm} / \mathrm{min}$, voltage at $15 \mathrm{~V}$, and Inter-Electrode Gap at $0.5 \mathrm{~mm}$. The minimum Ra have obtained with electrolyte concentration at $80 \mathrm{~g} / \mathrm{l}$, feed rate at $0.0468 \mathrm{~mm} / \mathrm{min}$, voltage at 10V, and Inter-Electrode Gap at $0.5 \mathrm{~mm}$. This results has led to need studies on these parameters in Electrochemical Machining which are improving productivities and surface roughness of the products.

Key words: Electrochemical machining (ECM), Taguchi method, ANOVA, surface quality

\section{INTRODUCTION}

In recent years there are a large of advanced new materials and alloys which have been discovered but they are difficult to machine such as super alloys, alloys steel, tool steel, and stainless steel with conventional machining methods ${ }^{1}$. This demands leads to several problems, and some feasible solutions would be solved in the future. Thus, new machine methods must be taken to mitigate the problems of urgent demands that they are beneficial methods called Non - Traditional Manufacturing (NTMPs). And, Electrochemical Machining (ECM) is one of the widely used Non - Traditional Machining processes. ECM principle is based on the phenomenon of electrolysis, whose laws were established by Faraday in 1833. "Faraday believes that if two conductive poles are placed in a conductive electrolyte bath and energized by a current, metal may be depleted from the positive pole (anode) and plated onto the negative pole (cathode)" ${ }^{1}$. The first law states that the amount of electrochemical dissolution or deposition is proportional to amount of charge passed through the electrochemical cell, which may be descried as in (1):

$$
m \sim Q
$$

Where:

$\mathrm{m}$ - Mass of material dissolved or deposition;

$\mathrm{Q}$ - Amount of charge passed

And, the second of Faraday law states that the amount of material deposited or dissolved further depends on Electrochemical Equivalence of the materials that is again the ratio of the atomic weight and valency, which may be showed as in (2):

$$
m=\frac{I t \varepsilon}{F}
$$

Where:

$\mathrm{m}=$ weight of a material $(\mathrm{g})$.

$\mathrm{I}=$ Current $(\mathrm{A})$.

$\mathrm{t}=$ machining time $(\mathrm{sec})$

$\varepsilon=$ gram equivalent weight of the material.

$\mathrm{F}=$ constant of proportionality - Faraday $(96,500$ coulombs). 
ECM equipment consists of three sub - equipment: machining setup, control unit and electrolyte circulation system. ECM process is performed without physical contact between the tool and the work - piece in contrast to the mechanical machining, and without strong heating in the machining zones in distinction to the methods like Electrical Discharge Machining - EDM. Therefore, no surface metal layer with mechanical distortion, comprehensive stresses, cracks, and thermal distortion forms in ECM. Besides, the numbers of these advantages of this process which are its applicability regardless of material hardness, no tool wear, high material removal rate and production of components of complex geometry. Despites these advantages it has been developed and applied in aerospace, aeronautics, defence, medical industries and other industries ${ }^{1-3}$.

It is true that surface quality has become significant because of increased quality demands. Moreover, surface roughness is one of major quality attributes of ECM products beside material removal rates, accuracy and performance of machining. Hence, a lots of investigations have attempted the study of the effects of multiple machining parameters on surface roughness. The effects of a pulsating electrolyte during the electrochemical machining process on surface roughness and material removal rate have been successfully studied through experimentations, and obtained lower surface roughness and higher material removal rate on Ti6Al4V sample machined by ECM. The minimum surface roughness $\mathrm{R}_{a}$ of $0.53 \mu \mathrm{m}$ and maximum MRR of $0.39 \mathrm{~g} / \mathrm{min}$ are observed by using a pulsating electrolyte ${ }^{2}$. Weidong Liu et al. ${ }^{4}$ focused to study the effects of main parameters like the composition and concentration of electrolyte, machining voltage, electrolyte flow rate, and Inter Electrode Gap (IEG) on machining performance in Jet electrochemical machining of TB6 titanium alloy. From experiment results, $24 \mathrm{~V}$ voltage, $0.6 \mathrm{~mm}$ IEG, $2.11 / \mathrm{min}$ flow rate and $15 \%$ sodium chloride electrolyte are selected as control parameters. Material removal rate of $10.062 \mathrm{~g} / \mathrm{min}$, surface roughness of $0.231 \mu \mathrm{m}$ and average overcut of $1.01 \mathrm{~mm}$ are observed when the optimum parameters are used. Milan Kumar et al. ${ }^{5}$ presented the effects of process parameters on MRR and surface roughness characteristics (centre line average roughness: $\mathrm{R}_{a}$, root mean square roughness: $\mathrm{R}_{q}$, skewness: $\mathrm{R}_{s k}$, kurtosis: $\mathrm{R}_{k u}$ and mean line peak spacing: $\mathrm{R}_{s m}$ ), and parametric optimization of process parameters in ECM of EN31 tool steel using grey relation analysis. The experimental results show that maximum MRR and minimum surface roughness have obtained with electrolyte concentration $10 \%$, voltage $10 \mathrm{~V}$, feed rate $0.25 \mathrm{~mm} / \mathrm{min}$ and
IEG 0.2mm. Jerzy Kozak and Maria Zybura - Skrabalak ${ }^{6}$ presents some features of ECM processes, such as the effect of heterogeneous structure of material work - piece and the influence hydrodynamic instability of anode boundary layer on the surface roughness. A mathematical model was developed to simulate the evolution of surface profiles during electrochemical machining of alloys with the heterogeneous structure. Results of computer simulation and an analysis of the effects of various ECM factors and the structure of the work - piece material, on surface roughness and its parameters is done. The experimental investigations confirmed the effect of hydrodynamic instability of boundary layer on micro topography of machined surface done. H.M.Osman and M.AbdelRahman ${ }^{7}$ investigates integrity of surfaces produced by electrochemical machining. M.Sankar et al. ${ }^{8}$ conducted to optimize main parameters such as voltage, feed rate, and current, were optimized based on multiple responses. The results show that feed rate and applied voltage are the most significant parameters which affect multiple machining responses simultaneously. Optimization of machining parameters in ECM of Al/B4C composites using Taguchi Method was reported by S. R. Rao ${ }^{9}$. There are 27 tests to study the effects of various parameters like applied voltage, feed rate, electrolyte concentration and percentage of reinforcement on Material Removal Rate (MRR), surface roughness ( $\mathrm{Ra}$ ) and radial overcut (ROC). A Rotary U Shaped Tool is applied to investigate the MRR, overcut diameter and overcut depth of AISI P20 work - piece. Four parameters were chosen as process variables: feed rate, voltage, electrolyte concentration and tool diameter. From these results, MRR increase with increasing the feed rate, voltage and electrolyte concentration but decreases with increasing the tool diameter. Both overcut and over depth which are increasing with increasing feed, voltage, and electrode diameter but decreases with increasing electrolyte concentration ${ }^{10}$.

This paper deals with the effects of these parameters and optimization of the ECM process based on Taguchi techniques. From previously literatures, in this work two contradicting response parameters Material Removal Rate (MRR) and surface roughness $\left(\mathrm{R}_{a}\right.$ ) were considered for analysis (MRR is to be maximized and $\mathrm{R}_{a}$ is to be minimized). There are consists of four input parameters which are electrolyte concentration, feed rate, voltage and Inter-Electrode Gap as process variables and Aluminium (Al) were machined by electrochemical machining process. 


\section{EXPERIMENTAL PROCEDURES}

Experiments are conducted on ECM equipment as in Figure 1 and based on Taguchi's design of experiments.

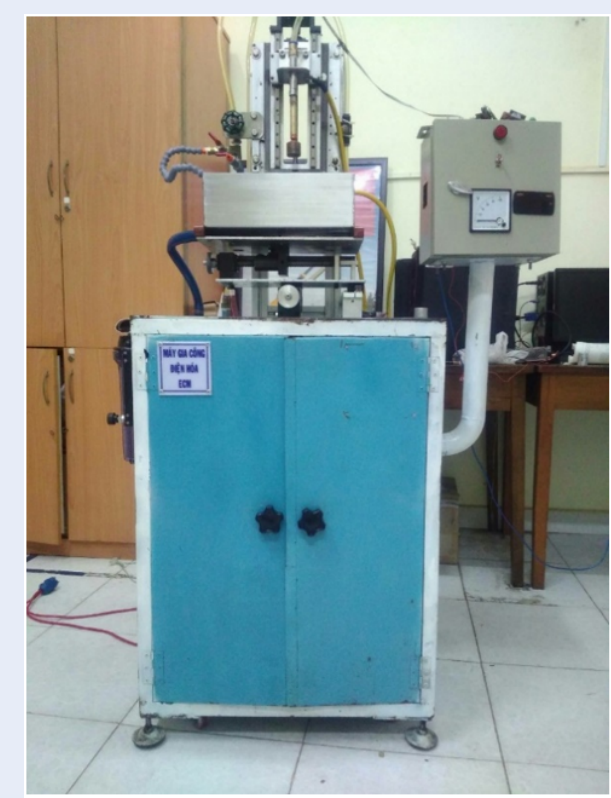

Figure 1: ECM Machine

As above introduction tab, ECM setup in experiment consists of control panel, machining chamber, and electrolyte system. The work-piece is located in a safety box and to be fixed inside the chamber and a tool is attracted to the main crew which driven by a stepper motor. Applied voltage and feed rate which are controlled by control panel. And, Aluminum samples of $25 \mathrm{~mm}$ diameter $\mathrm{x} 25 \mathrm{~mm}$ height and $30 \mathrm{~mm}$ diameter $\mathrm{x} 25 \mathrm{~mm}$ height of the tool is made up of copper with a circular cross section with $2 \mathrm{~mm}$ internal hole. Figure 2 shown dimensions of a tool and work - piece.

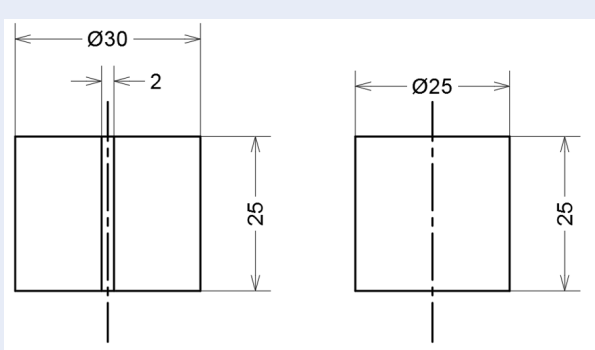

Figure 2: Dimensions of Tool and Work - Piece
Electrolyte to be able to through the central hole of $2 \mathrm{~mm}$ of the tool and into machining zones. Figure 3 shown experiment setup.

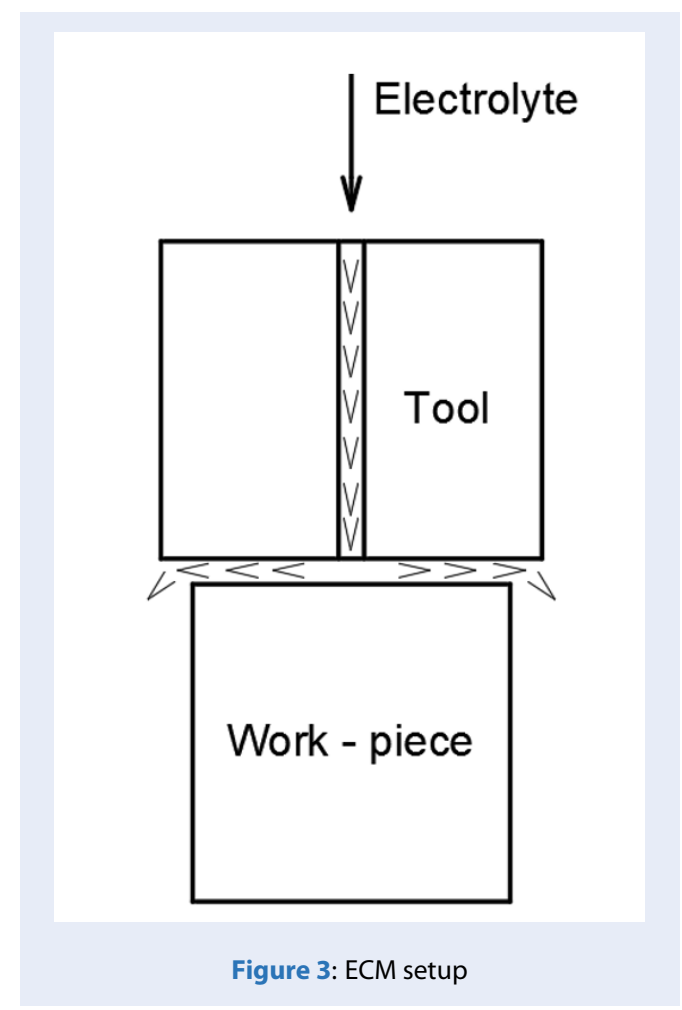

Figure 4 is showed input factors and these responses. Based on Rebecca and Ivanov (2016) ${ }^{11} \mathrm{NaCl}$ solution is chosen as electrolyte, because it has no passivation effect on the surface of the job. Reference ${ }^{1}$ electrolyte concentration is selected in the range of $80-100 \mathrm{~g} / \mathrm{lit}$. Because low voltages lead to low material removal rate and high surface roughness in electrochemical machining process ${ }^{9}$. Thus, applied voltage in ECM process it is possible to vary range of from 5 to $30 \mathrm{~V}$ and feed rate from $0.2 \mathrm{~mm} / \mathrm{min}$ to $2 \mathrm{~mm} / \mathrm{min}^{9}$. But, they depend on experiments conditions, applied voltage the range of $10-20 \mathrm{~V}$ and the range of feed rate from $0.0375-0.0562 \mathrm{~mm}$. The smaller the inter- electrode gap, the smaller the applied potential has to be reach the machining potential as the ohmic drop caused by the electrolyte resistance is reduced ${ }^{11}$. Thus, IEGs are selected in the range of $0.5-1.5 \mathrm{~mm}^{5,12}$.

Tables 1 and 2 are showed input levels of factors and these responses, L27 Taguchi Orthogonal Arrays.

MRR is measured from weight loss. And, surface roughness $\left(\mathrm{R}_{a}\right)$ is measured with Mitutoyo SJ-210 


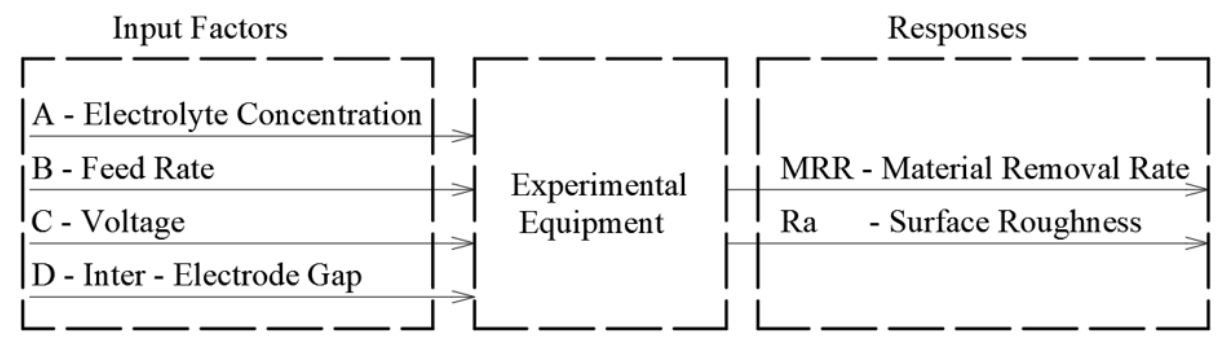

Figure 4: Input Factor and Output Responses

Table 1: Four input factors and their levels.

\begin{tabular}{llll}
\hline Symbol & Level 1 & Level 2 & Level 3 \\
A & 80 & 90 & 100 \\
B & 0.0375 & 0.0468 & 0.0562 \\
C & 10 & 15 & 20 \\
D & 0.5 & 1 & 1.5 \\
\hline
\end{tabular}

A: Electrolyte concentration (g/l); B: Feed rate ( $\mathrm{mm} / \mathrm{min})$; C: Voltage (V); D: Inter - Electrode Gap (mm)

Surface Roughness (ISO 1997, $\lambda=0.8, \mu \mathrm{m}$ ). The responses MRR calculated by following (3):

$$
M R R=\frac{m_{b}-m_{a}}{t}
$$

$\mathrm{m}_{a}$ : mass of Work - piece before machining (gram)

$\mathrm{m}_{b}$ : mass of Work - piece after machining (gram)

$\mathrm{t}$ : machining time $(\mathrm{min})$

\section{METHODOLOGYS}

\section{Regression analysis}

Regression analysis is a statistical tool for estimating the relationships among variables. Regression analysis helps one understand how the typical value of the dependent variable changes when any one of the independent variables is varied. It is also used to understand which among the independent variables are related to the dependent variable and to explore the forms of these relationships ${ }^{11,13}$. The general form of a multiple regression model is as follows:

$$
\begin{aligned}
& \text { Dependent variable } \\
& \begin{array}{r}
=b 0+b 1+b 2(\text { Independent variable } 2) \\
+b 3(\text { Independent variable } 3)
\end{array}
\end{aligned}
$$

Where $b 1, b 2, b 3, \ldots$ are estimates of the independent variables $1,2,3, \ldots$ and $\varepsilon$ is the error.

\section{Taguchi Method}

One of the advantages of the Taguchi method is that it uses a special design of orthogonal arrays to study the scope of a research project or the entire parameter space with a small number of experiments ${ }^{11}$. From results, Taguchi method allows for the analysis of many different parameters without a prohibitively high amount of experimentation.

The $\mathrm{S} / \mathrm{N}$ ratio for the Larger - to - better is given Taguchi as (5):

$$
\frac{S}{N}=-10 \log _{10}\left[\frac{1}{n} \sum_{1}^{n} \frac{1}{y^{2}}\right]
$$

Where:

$\mathrm{y}$ - observed data.

$\mathrm{n}$ - number of observations.

The $\mathrm{S} / \mathrm{N}$ ratio for the Smaller - to - better is given Taguchi as (6):

$$
\frac{S}{N}=-10 \log _{10}\left[\sum_{1}^{n} \frac{y^{2}}{n}\right]
$$

\section{Analysis of Variance (ANOVA)}

Analysis of variance (ANOVA) is a potential technique used to study the significance of the all parameters and their interactions by comparing the mean square with an estimate of the experimental error at a specific confidence level ${ }^{5,9}$. In present paper, ANOVA is performed using Minitab 18. The relative influence of the parameters is measured by total sum of square value (SST) by following (7):

$$
\frac{S}{N}=-10 \log _{10}\left[\sum_{1}^{n} \frac{y^{2}}{n}\right]
$$

Where $n$ is the number of experiments in the orthogonal array, $n_{i}$ is the mean $S / N$ ratio for the $i_{t h}$ experiment and $n_{m}$ is the total mean $S / N$ ratio of all 


\begin{tabular}{|c|c|c|c|c|c|}
\hline A & B & $\mathrm{C}$ & $\mathrm{D}$ & MRR & $\mathrm{Ra}$ \\
\hline 1 & 1 & 1 & 1 & 1.552 & 4.428 \\
\hline 1 & 2 & 2 & 1 & 1.454 & 5.604 \\
\hline 1 & 3 & 3 & 1 & 1.371 & 4.17 \\
\hline 2 & 1 & 2 & 2 & 1.425 & 4.768 \\
\hline 2 & 2 & 3 & 2 & 1.336 & 4.885 \\
\hline 2 & 3 & 1 & 2 & 1.543 & 4.236 \\
\hline 3 & 1 & 3 & 3 & 1.314 & 6.275 \\
\hline 3 & 2 & 1 & 3 & 1.563 & 6.222 \\
\hline 3 & 3 & 2 & 3 & 1.435 & 6.494 \\
\hline 3 & 1 & 1 & 3 & 1.544 & 4.248 \\
\hline 3 & 2 & 2 & 3 & 1.472 & 6.523 \\
\hline 3 & 3 & 3 & 3 & 1.322 & 6.543 \\
\hline 1 & 1 & 2 & 1 & 1.416 & 4.848 \\
\hline 1 & 2 & 3 & 1 & 1.365 & 6.807 \\
\hline 1 & 3 & 1 & 1 & 1.523 & 5.28 \\
\hline 2 & 1 & 3 & 2 & 1.346 & 6.838 \\
\hline 2 & 2 & 1 & 2 & 1.551 & 4.434 \\
\hline 2 & 3 & 2 & 2 & 1.42 & 4.534 \\
\hline 2 & 1 & 1 & 2 & 1.561 & 5.737 \\
\hline 2 & 2 & 2 & 2 & 1.428 & 4.967 \\
\hline 2 & 3 & 3 & 2 & 1.396 & 5.305 \\
\hline 3 & 1 & 2 & 3 & 1.429 & 6.836 \\
\hline 3 & 2 & 3 & 3 & 1.314 & 5.032 \\
\hline 3 & 3 & 1 & 3 & 1.525 & 4.728 \\
\hline 1 & 1 & 3 & 1 & 1.324 & 6.34 \\
\hline 1 & 2 & 1 & 1 & 1.596 & 5.939 \\
\hline 1 & 3 & 2 & 1 & 1.427 & 6.682 \\
\hline
\end{tabular}

$\operatorname{MRR}(\mathrm{g}), \operatorname{Ra}(\mu \mathrm{m})$

experiments. The percentage contribution $\mathrm{P}$ can be calculated as:

$$
P=\frac{S S_{d}}{S S_{T}}
$$

Where, $\mathrm{SS}_{d}$ is the sum of squared deviations. Further, the Fisher's F-ratio, the ratio between the regression mean square and the mean square error, is used to identify the most significant factor on the performance characteristic.

The $P$-value reports the significance level (suitable and unsuitable). Percent (\%) represents the significance rate of the machining parameters on the response.

\section{RESULTS ANALYSIS AND DISCUSSION}

\section{Effects on MRR}

From experiment results, the machinability of ECM depends on electrolyte concentration, feed rate, voltage and IEG. The influence of various machining parameters on MRR is shown in Figure 5. The InterElectrode Gap between tool and work - piece has ex- 
tremely effect on MRR and it increases with decreases in IEG. And then voltage, and then feed rate, and then feed rate. And, regression models for MRR are decried by (9):

$\mathrm{MRR}=1.6562+0.00039 \mathrm{~A}-0.00611 \mathrm{~B}+0.00283 \mathrm{C}$

$0.10389 \mathrm{D}(9)$

In Table 3, ANOVA of MRR is presented with all the terms. After eliminating interaction of process parameter like $\mathrm{B}^{\star} \mathrm{C}, \mathrm{B}^{\star} \mathrm{D}$, and $\mathrm{C}^{\star} \mathrm{D}$. It can be proving that electrolyte concentration $\mathrm{NaCl}$, feed rate, voltage, and Inter-Electrode Gap effects on MRR by $0.039 \%, 0.4 \%$, $0.75 \%$ and $93.56 \%$, respectively.

In Table 4 showed the optimal machining performance for the Electrolyte concentration level 100g/l (level 3), Feed rate $0.0375 \mathrm{~mm} / \mathrm{min}$ (level 1), Voltage $15 \mathrm{~V}$ (level 2), IEG $0.5 \mathrm{~mm}$ (level 1). In which there IEG is important and then voltage, and then feed rate and then electrolyte concentration.

The estimated model coefficients for $\mathrm{SN}$ ratios are shown in Table 5. Parameter results are standard deviation of error $\mathrm{S}=0.0682$, amount of variation $\mathrm{R}^{2}=$ $99.63 \%$ and $\mathrm{R}^{2}$ (adj.) $=98.40 \%$. And comparing the $\mathrm{P}$ value is less than or equal to 0.05 it can be concluded that the effect is significant, otherwise is not significant.

The residual plots of MRR is showed in Figure 6.

The residual plot in the graph for normal probability plot indicate the data are normally distributed and variables are influencing the response. Standardized residues are between 0.08 and 0.08 .

The residuals versus fitted value indicate the variation is constant.

The histogram proved the data are not normally distributed it may be due to the fact that the number of points are very less.

Residual versus order of the data indicates that there are systematic effects in the data due to data collection order.

\section{Effects on $R a$}

From experiment results, the machinability of ECM depends on electrolyte concentration, feed rate, voltage and IEG. The influence of various machining parameters on the surface roughness $(\mathrm{Ra})$ is shown in Figure 7. The Inter-Electrode Gap between tool and work - piece has extremely effect on $\mathrm{R}_{a}$ and it increases with decreases in IEG. And then voltage, and then feed rate, and then feed rate. And, regression models for Ra are decried by (10):

$\mathrm{Ra}=4.437+0.417 \mathrm{~A}+0.39511 \mathrm{~B}+0.084 \mathrm{C}-0.303 \mathrm{D}$ (10)

In Table 6, ANOVA of $\mathrm{Ra}$ is presented with all the terms. After eliminating interaction of process parameter like $B^{\star} C, B^{\star} D$, and $C^{\star} D$. It can be proving that electrolyte concentration $\mathrm{NaCl}$, feed rate, voltage, and Inter-Electrode Gap effect the Surface Roughness by $0.15 \%, 16 \%, 0.42 \%$ and $39.31 \%$, respectively.

In Table 7 showed the optimal machining performance for the Electrolyte concentration level $80 \mathrm{~g} / \mathrm{l}$ (level 1), Feed rate $0.0468 \mathrm{~mm} / \mathrm{min}$ (level 2), Voltage $10 \mathrm{~V}$ (level 1), IEG $0.5 \mathrm{~mm}$ (level 1). In which there IEG is important and then feed rate, and then voltage and then electrolyte concentration.

The estimated model coefficients for $\mathrm{SN}$ ratios are shown in Table 8. Parameter results are standard deviation of error $\mathrm{S}=0.4297$, amount of variation $\mathrm{R}^{2}=$ $94.02 \%$ and $\mathrm{R}^{2}$ (adj.) $=74.11 \%$. And comparing the $\mathrm{P}$ value is less than or equal to 0.05 it can be concluded that the effect is significant, otherwise is not significant.

The residual plots of MRR is showed in Figure 8. The residual plot in the graph for normal probability plot indicate the data are normally distributed and variables are influencing the response.

The residuals versus fitted value indicate the variation is constant.

The histogram proved the data are not normally distributed it may be due to the fact that the number of points are very less.

Residual versus order of the data indicates that there are systematic effects in the data due to data collection order.

\section{CONCLUSIONS}

In the present study, four factors are considered electrolyte concentration, feed rate, voltage and InterElectrode Gap . Aluminium as a Work - piece and 27 experiments conducted to obtain an optimum level in achieving high material removal rate and minimum surface roughness. And, to determine effect levels on two outputs.

The IEG between tool and workpiece has extremely effect on MRR and it increase with diseases in InterElectrode Gap. And then voltage, and then Feed rate, and then electrolyte concentration.

Among the four process parameters, The IEG between tool and workpiece influences highly on surface roughness and it diseases with diseases in InterElectrode Gap. Follwed by feed rate, and then electrolyte concentration, and then voltage Form results:

1. Maximum MRR at Electrolyte concentration level $100 \mathrm{~g} / \mathrm{l}$ (level 3), Feed rate $0.0375 \mathrm{~mm} / \mathrm{min}$ (level 1), Voltage 15V (level 2), IEG 0.5mm (level $1)$. 
Table 3: Analysis of Variance for SN ratios of MRR

\begin{tabular}{lllllll}
\hline Source & DF & Seq SS & Adj SS & Adj MS & F & P \\
A & 2 & 0.00297 & 0.00297 & 0.00149 & 0.32 & 0.738 \\
& 2 & 0.03061 & 0.03061 & 0.01531 & 3.29 & 0.108 \\
C & 2 & 0.05664 & 0.05664 & 0.02832 & 6.09 & 0.036 \\
D & 2 & 7.05368 & 7.05368 & 3.52684 & 758.55 & 0 \\
Error & 18 & 0.39517 & 0.39517 & 0.09647 & & \\
Total & 26 & 7.53908 & & & & \\
\hline
\end{tabular}

Table 4: Taguchi analysis response for MRR: Large is better

\begin{tabular}{lllll}
\hline Level & $\mathrm{A}$ & $\mathrm{B}$ & $\mathrm{C}$ & $\mathrm{D}$ \\
1 & 3.173 & $3.197^{*}$ & 3.116 & $3.811^{*}$ \\
2 & 3.153 & 3.184 & $3.227^{*}$ & 3.130 \\
3 & $3.176^{*}$ & 3.120 & 3.158 & 2.560 \\
Delta & 0.024 & 0.077 & 0.111 & 1.250 \\
Rank & 4 & 3 & 2 & 1 \\
\hline
\end{tabular}

Table 5: Estimated model coefficients for SN ratios of MRR

\begin{tabular}{lllll}
\hline Term & Coef & SE Coef & $\mathrm{T}$ & $\mathrm{P}$ \\
Constant & 3.16724 & 0.01312 & 241.358 & 0.000 \\
Electrol 2 & -0.01473 & 0.01856 & -0.794 & 0.057 \\
Feed Rat 1 & 0.02995 & 0.01856 & 1.614 & 0.058 \\
Voltage 2 & 0.06018 & 0.01856 & 3.243 & 0.018 \\
Inter 1 & 0.64361 & 0.01856 & 34.681 & 0.000 \\
\hline
\end{tabular}

$\mathrm{S}=0.0682 \mathrm{R}-\mathrm{Sq}=99.63 \% \mathrm{R}-\mathrm{Sq}(\mathrm{adj})=98.40 \%$

Table 6: Analysis of Variance for SN ratios of $\mathbf{R}_{a}$

\begin{tabular}{|c|c|c|c|c|c|c|}
\hline Source & $\mathrm{DF}$ & Seq SS & Adj SS & Adj MS & $\mathrm{F}$ & \\
\hline \multirow[t]{2}{*}{ A } & 2 & 0.0282 & 0.02818 & 0.01409 & 0.08 & 0.927 \\
\hline & 2 & 2.9649 & 2.96495 & 1.48247 & 8.03 & 0.02 \\
\hline C & 2 & 0.0771 & 0.07706 & 0.03853 & 0.21 & 0.817 \\
\hline D & 2 & 7.2898 & 7.28977 & 3.64488 & 19.74 & 0.002 \\
\hline Error & 6 & 8.1822 & 8.1822 & 1.9532 & & \\
\hline Total & 26 & 18.5422 & & & & \\
\hline
\end{tabular}

A: Electrolyte concentration ( $\mathrm{g} / \mathrm{l}) ; \mathrm{B}$ : Feed rate ( $\mathrm{mm} / \mathrm{min}) ;$ C: Voltage $(\mathrm{V})$; D: Inter - Electrode Gap ( $\mathrm{mm})$ 


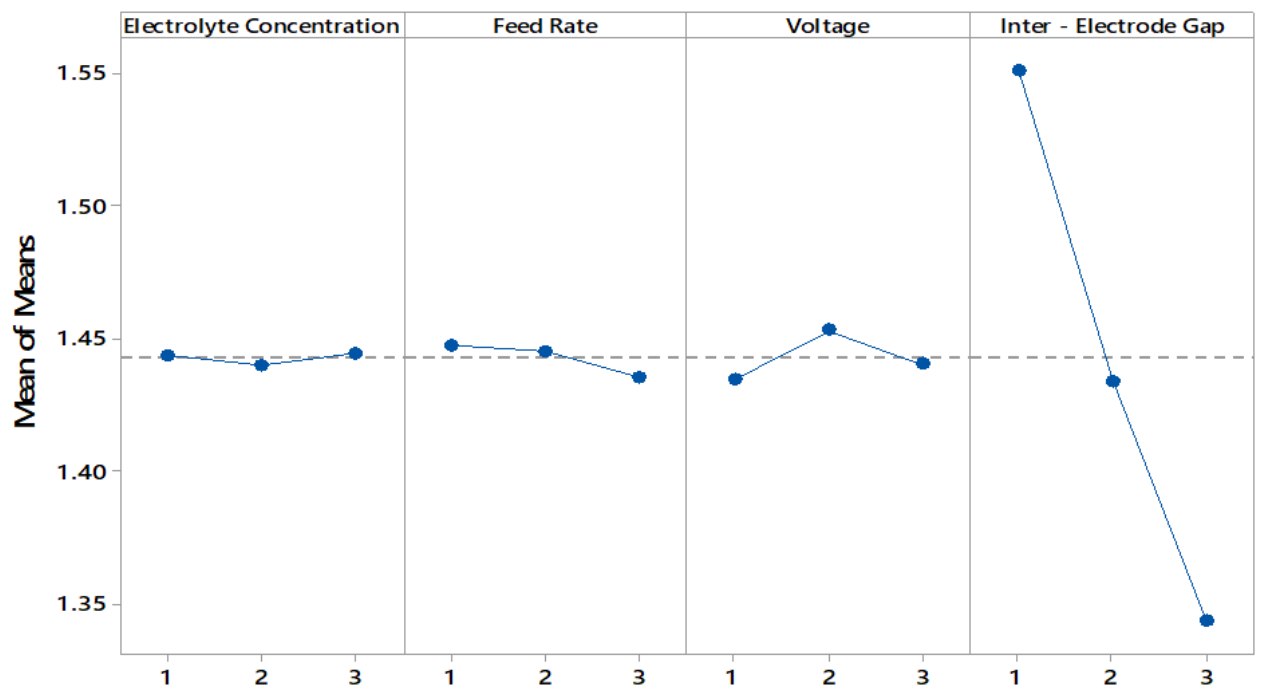

Figure 5: Main effects of $\mathrm{SN}$ ratios for MRR

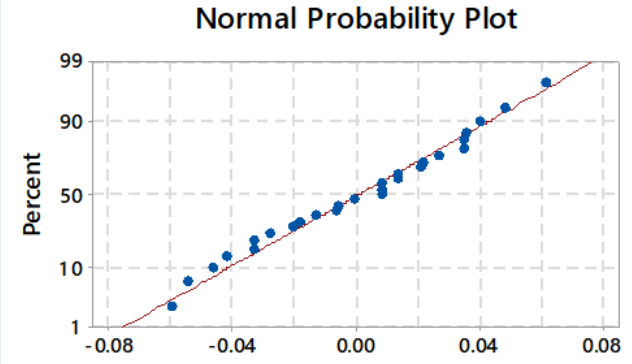

(a) Residual

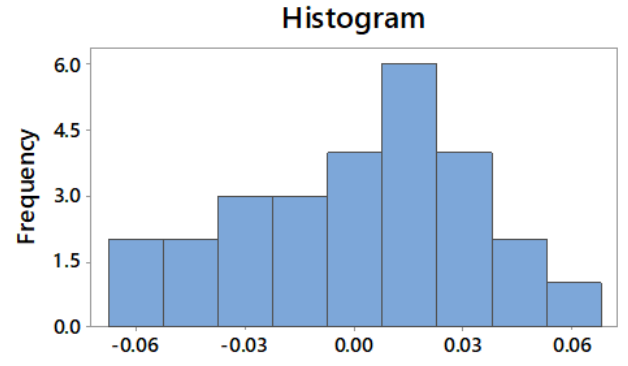

(c) Standardized Residual

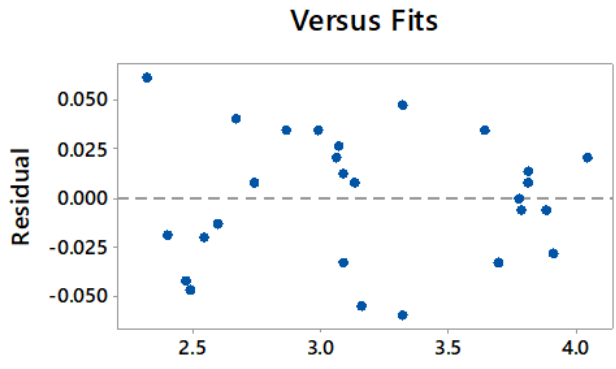

(b) Fitted Value

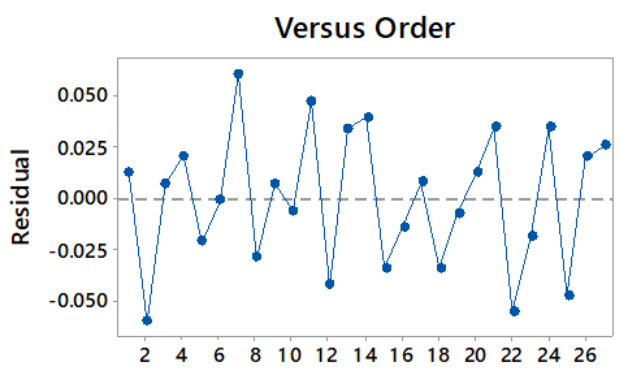

(d) Observation Order

Figure 6: Residual Plots for MRR 


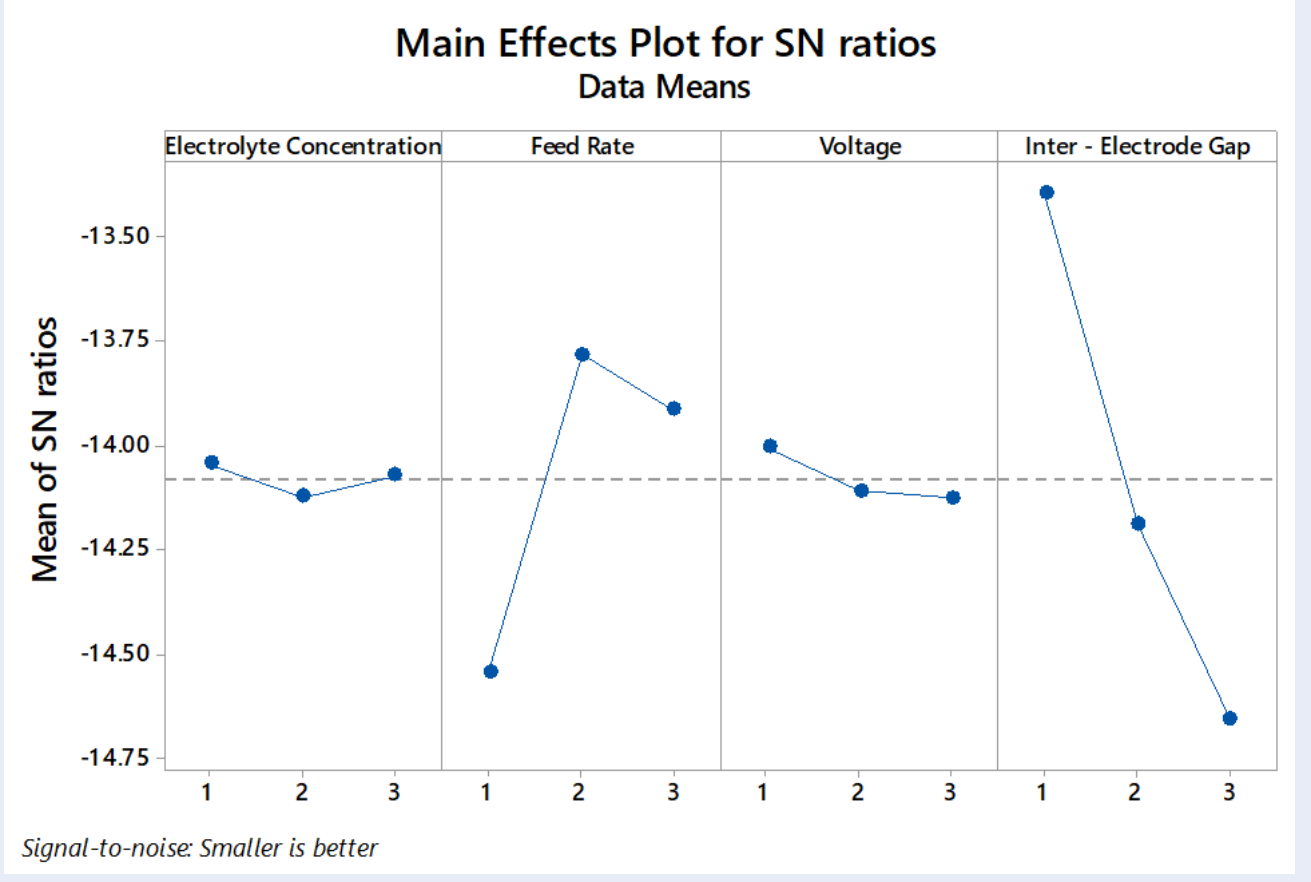

Figure 7: Main effects of $\mathrm{SN}$ ratios for Ra

Table 7: Taguchi analysis response for $\mathbf{R}_{a}$ : Smaller is better

\begin{tabular}{lllll}
\hline Level & $\mathrm{A}$ & $\mathrm{B}$ & $\mathrm{C}$ & $\mathrm{D}$ \\
1 & $-14.05^{*}$ & -14.54 & $-14.01^{*}$ & $-13.40^{*}$ \\
2 & -14.12 & $-13.78^{*}$ & -14.11 & -14.19 \\
3 & -14.07 & -13.92 & -14.13 & -14.66 \\
Delta & 0.08 & 0.76 & 0.12 & 1.26 \\
Rank & 4 & 2 & 3 & 1 \\
\hline
\end{tabular}

A: Electrolyte concentration ( $\mathrm{g} / \mathrm{l})$; B: Feed rate ( $\mathrm{mm} / \mathrm{min})$; C: Voltage (V); D: Inter - Electrode Gap (mm)

Table 8: Estimated model coefficients for $\mathbf{S N}$ ratios of $\mathbf{R}_{a}$

\begin{tabular}{lllll}
\hline Term & Coef & SE Coef & T \\
Constant & -14.081 & 0.0827 & -170.269 & 0 \\
A (1) & 0.035 & 0.11695 & 0.299 & 0.775 \\
B(2) & 0.2981 & 0.11695 & 2.549 & 0.044 \\
C(1) & 0.0749 & 0.11695 & 0.641 & 0.545 \\
$\mathrm{D}(1)$ & 0.6843 & 0.11695 & 5.851 & 0.001 \\
\hline
\end{tabular}

$\mathrm{S}=0.4297 ; \mathrm{R} 2=94.02 \%$ and $\mathrm{R} 2$ (adj.) $=74.11 \%$. 


\section{Residual Plots for SN ratios}
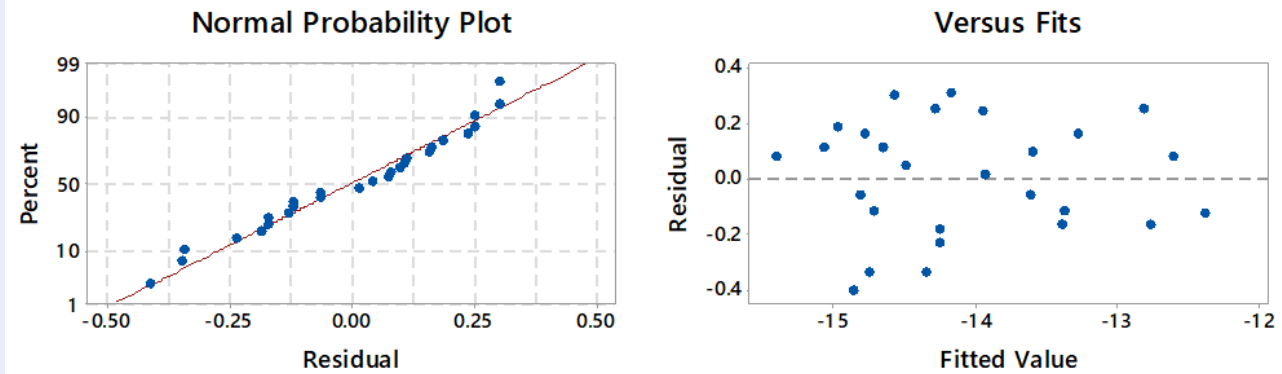

Histogram
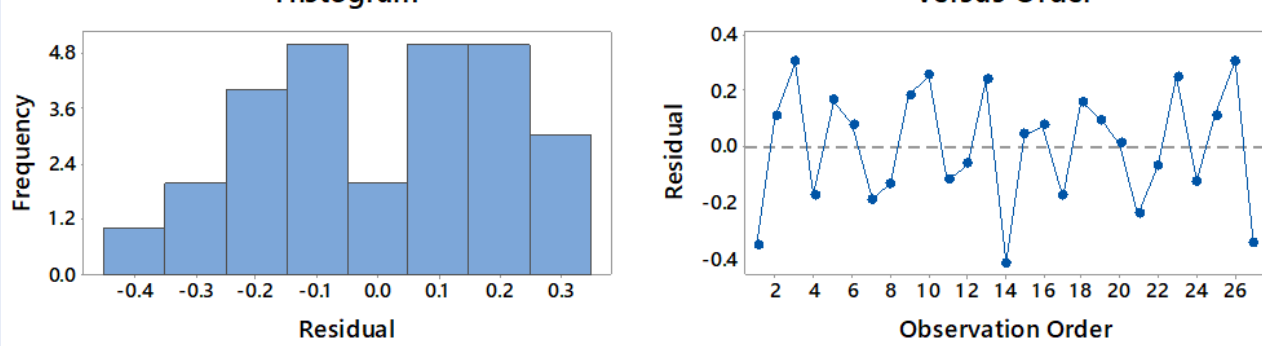

Figure 8: Residual Plots for Ra

2. Minimum $\mathrm{R}_{a}$ at the Electrolyte concentration level $80 \mathrm{~g} / \mathrm{l}$ (level 1), Feed rate $0.0468 \mathrm{~mm} / \mathrm{min}$ (level 2), Voltage 10V (level 1), IEG 0.5mm (level $1)$.

\section{ACKNOWLEDGEMENT}

One of us would like to thank lecturers of Faculty of Mechanical Engineering at Ho Chi Minh City University Technology. Who are supported us during conducting this investigation.

\section{ABBREVIATIONS}

NTMPs: Non - Traditional Manufacturing

ECM: Electrochemical Machining

S/N: Signal-To-Noise

ANOVA: The Analysis of Variance

EDM: Electrical Discharge Machining

MRR: Material Removal Rate

IEG: Inter - Electrode Gap

$\mathbf{R}_{a}$ : Surface Roughness

ROC: Radial overcut

\section{CONFLICT OF INTEREST}

The authors hereby warrant that this paper is no conflict of interest with any publication.

\section{AUTHOR'S CONTRIBUTION}

Ms. Nguyen Thi Bich Nhung played a role as an executer, collected the experimental data, analyzed the statistic and

wrote the paper.

Dr. Dao Thanh Liem contributed for writing orient paper.

Dr. Truong Quoc Thanh played a role as a corresponding author.

\section{REFERENCES}

1. Rao RV. "Modeling and Optimization of Modern Machining Processes," in Advanced Modeling and Optimization of Manufacturing Processes, eds. London. UK: Springer-Verlag. 2010;p. 222-240. Available from: https://doi.org/10.1007/9780-85729-015-1_2.

2. Qu NS, Fang X, Zhang Y, Zhu D. Enhancement of surface roughness in electrochemical machining of Ti6Al4V by pulsating electrolyte. Int J Adv Manuf Technol;69(9-12):2703-2709. Available from: https://doi.org/10.1007/s00170-013-5238-9.

3. Kumar M, Mahto PK, Kushwaha D, Singh N. Electrochemical machining: review of historical and recent developments. Presented at ICRISEM-16. 2016;Available from: www. conferenceworld.in.

4. Weidong L, Sansan A, Yang L, Zhengming W, Zhen L, Zhiping W, et al. Jet electrochemical machining of TB6 titanium alloy. Int J Adv Manuf Technol. 2016;90(1):2397-2409. Available from: https://doi.org/10.1007/s00170-016-9500-9.

5. Das M, Kumar K, Barman TK, Sahoo. Optimization of Surface Roughness and MRR in Electrochemical Machining of EN31 Tool Steel using Grey-Taguchi Approach. Procedia Materials Science. 2014;6(1):729-740. Available from: https://doi.org/ 10.1016/j.mspro.2014.07.089.

6. Kozaka J, Zybura-Skrabalak M. Some problems of surface roughness in electrochemical machining (ECM). Procedia CIRP. 2016;42(1):101-106. Available from: https://doi.org/10. 1016/j.procir.2016.02.198. 
7. Osman HM, Abdel-Rahman. Integrity of surfaces produced by electrochemical machining. Journal of Materials Processing Technology. 1993;37(1-4):667-677. Available from: https: //doi.org/10.1016/0924-0136(93)90126-Q.

8. Sankar M, Gnanavelbabu A, Baskaran R. Optimization of Surface Roughness in Electro Chemical Machining. Applied Mechanics and Materials. 2014;606(1):193-197. Available from: https://doi.org/10.4028/www.scientific.net/AMM.606.193.

9. Rao SR, Padmanabhan G. Optimization of Machining parameters in ECM of Al/B4C Composites Using Taguchi Method. Int J Appl Sci Eng. 2014;12(2):87-97.

10. Biswas CK. Optimization of Process Parameters in ECM by using Rotary U Shaped Tool. 209ME2198, Orissa, India. 2010;.
11. Leese RJ, Ivanov A.

Electrochemical micromaching: An introduction. Advances in Mechanical Engineering. 2016:8(1):1-13. Available from: https: //doi.org/10.1177/1687814015626860.

12. Sahu SN, Nayak D, Rana HK. Optimization of ECM Process Parameter by Using Simulated Annealing Approach. ICETEM. 2013;2(6):18-21. Available from: 0.13140/RG.2.1.3655.8569.

13. Kacker R, Lagergren E, Filliben J. Taguchi's Orthogonal Arrays Are Classical Designs of Experiments. J Res Natl Inst Stand Teehnol. 1991;96(5):577. PMID: 28184132. Available from: https://doi.org/10.6028/jres.096.034. 


\title{
Ảnh hưởng thông số công nghệ trong gia công điện hóa đến chất lượng bề mặt
}

\author{
Nguyễn Thị Bích Nhung ${ }^{1}$, Đào Thanh Liêm² ${ }^{2}$ Trương Quốc Thanh ${ }^{2}$,*
}

${ }^{1}$ Công Ty TNHH Tu Vấn Dư Án SEAS, Số 8/19a Đường Nguyễn Thiện Thuật, Phiờng 24, Quân Bình Thanh, Thành Phố Hồ Chí Minh, Việt Nam

${ }^{2}$ Khoa Cơ Khí, Đai hoc Bách khoa, Đai học Quốc gia Tp.HCM, số 268 Đường Lý Thường Kiệt, Phường 14, Quận 10, Thành phố Hồ Chí Minh, Việt Nam

\section{Liên hệ}

Trương Quốc Thanh, Khoa Cơ Khí, Đại học Bách khoa, Đại học Quốc gia Tp.HCM, số 268 Đường Lý Thường Kiệt, Phường 14, Quận 10, Thành phố Hồ Chí Minh, Việt Nam

Email: tqthanh@hcmut.edu.vn

Lịch sử

- Ngày nhận: 10/10/2018

- Ngày chấp nhận: 23-12-2018

- Ngày đăng: 31-12-2019

DOI : 10.32508/stdjet.v3iSI1.725

\section{Check for updates}

\section{Bản quyền}

๑ ĐHQG Tp.HCM. Đây là bài báo công bố mở được phát hành theo các điều khoản của the Creative Commons Attribution 4.0 International license.

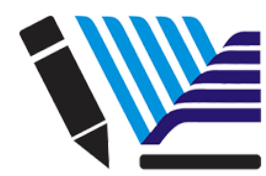

VNU-HCM Press

\section{TÓM TẮT}

Dựa vào những nghiên cứu liên quan đến lĩnh vực gia công điện hóa từ các nghiên cứu trên thế giới. Nhóm tác giả lựa chọn nghiên cứu ảnh hưởng của những thông số công nghệ quá trình gia công điện hoá (ECM) là nội dung chính của bài báo, những thông số công nghệ được đưa vào nghiên cứu đó là nồng độ chất điện phân, hiệu điện thế giữa hai điện cực, tốc độ tiến dụng cụ và khe hở giữa hai điện cực. Dung cu điện cực sử dụng là đồng có kích thước $\Phi 30 \mathrm{~mm} \times 25$ mm, đường kính lỗ $2 \mathrm{~mm}$ và vật liệu phôi sử dụng là ống. Nhôm tròn có kích thước $\Phi 25 \mathrm{~mm} \times 25 \mathrm{~mm}$. Thiết kế thực nghiệm dựa vào phương pháp Taguchi. Các bước bao gồm phân tích tỉ số nhiễu, phân tích ANOVA và phân tích hồi quy được áp dụng để xác định những mức độ tối ưu và nghiên cứu ảnh hưởng các thông số gia công lên chất lượng bề mặt. Cuối cùng các thực nghiệm đã được sử dụng để so sánh mức độ tối ưu của thí nghiệm thực tế và dựa vào phần mềm Taguchi. Kết quả thực nghiệm cho thấy khe hở giữa hai điện cực là thông số ảnh hưởng lớn nhất đến tốc độ ăn mòn vật liệu, và đồng thời đó cũng là thông số ảnh hưởng mạnh đến độ nhám bể mặt. Với nônng độ chất điện phân $100 \mathrm{gam} /$ lít, Tốc độ tiến dụng cụ là $0,0375 \mathrm{~mm} /$ phút, hiệu điện thế giữa dụng cụ và phôi là 15 Vol, Khe hở giữa hai điện cực là $0,5 \mathrm{~mm}$ thì tốc độ ăn mòn vật liệu đạt tối ưu. Độ nhám bề mặt nhỏ nhất tại nồng độ chất điện phân $80 \mathrm{gam} /$ lít, tốc độ tiến dụng cụ $0.0468 \mathrm{~mm} /$ phút, hiệu điện thế 10 vol, và khe hở giữa hai điện cực là $0.5 \mathrm{~mm}$. Từ đó có thể kết luận việc tối ưu các thông số công nghệ của quá trình gia công điện hóa là điều kiện tiên quyết nâng cao năng suất cũng như chất lượng bề mặt của sản phẩm.

Từ khoá: Gia công điện hóa, phương pháp Taguchi, Phân tích ANOVA, Chất lượng bề mặt
Trích dẫn bài báo này: Nhung N T B, Liêm D T, Thanh $\mathrm{T}$ Q. Ảnh hưởng thông số công nghệ trong gia công điện hóa đến chất lượng bề mặt. Sci. Tech. Dev. J. - Eng. Tech.; S2(SI1):SI80-SI91. 